\title{
The "Older Fill" of the Voidomatis Valley, North-west Greece and Its Relationship to the Palaeolithic Archaeology and Glacial History of the Region
}

\author{
G. N. Bailey ${ }^{a}$, J. Lewin ${ }^{b}$, M. G. Macklin ${ }^{c}$ and J. C. Woodward ${ }^{d}$
}

(Received 7 December 1988, revised manuscript accepted 13 October 1989)

\begin{abstract}
Late-Quaternary alluvial deposits in Mediterranean valleys have been divided into "Older" and "Younger" Fills. The Older Fills are generally coarse, are commonly calcreted and may be associated with isolated Palaeolithic artefacts of uncertain provenance. In broad terms the Older Fills were clearly deposited during cold stages of the Pleistocene. However, it has rarely proved possible to establish a more precise dating and correlation with specific Pleistocene stages, or a more precise identification of depositional environments and their relationship with, and impact on, human activity and land-use. The Voidomatis River of north-west Greece contains four main alluvial terraces which can be distinguished by lithological and mineralogical techniques. One of these, the Aristi unit, can be directly linked with glacial deposits in the headwaters. Comparison of dates for the Aristi unit with dated evidence of late Upper Palaeolithic sites in the lower reaches of the river gives a basis for assessing the impact of alluvial history on the Palaeolithic occupation of the area.
\end{abstract}

Keywords: GLACIATION, GREECE, KLITHI, OLDER FILL, PALAEOLITHIC, XRD ANALYSIS.

\section{Introduction}

The Voidomatis River has a $384 \mathrm{~km}^{2}$ catchment draining part of the Pindus Range in Epirus, north-west Greece (Figure 1) and can now provide useful information on the Older Fill from this region (Higgs \& Vita-Finzi, 1966; Vita-Finzi, 1969; Pope \& Van Andel, 1984). The valley contains four main alluvial terraces and fills (Table 1), the most prominent of which we have called the Aristi unit. This unit forms a striking alluvial terrace averaging $12.4 \mathrm{~m}$ above the present level of the river bed. Its sediments reach a maximum thickness of at least $26 \mathrm{~m}$, and consist almost entirely of flat-bedded, massive, partly-cemented, matrix-rich cobble gravels with occasional boulders. There are two

${ }^{a}$ Department of Archaeology, University of Cambridge, Downing Street, Cambridge CB2 3DZ, U.K.

${ }^{3}$ Institute of Earth Studies, University College of Wales, Aberystwyth SY23 3DB, U.K.

"Department of Geography, University of Newcastle, Newcastle-upon-Tyne NEI 7RU, U.K.

The Godwin Laboratory, Sub-department of Quaternary Research, University of Cambridge, Cambridge CB2 3RS, U.K. 


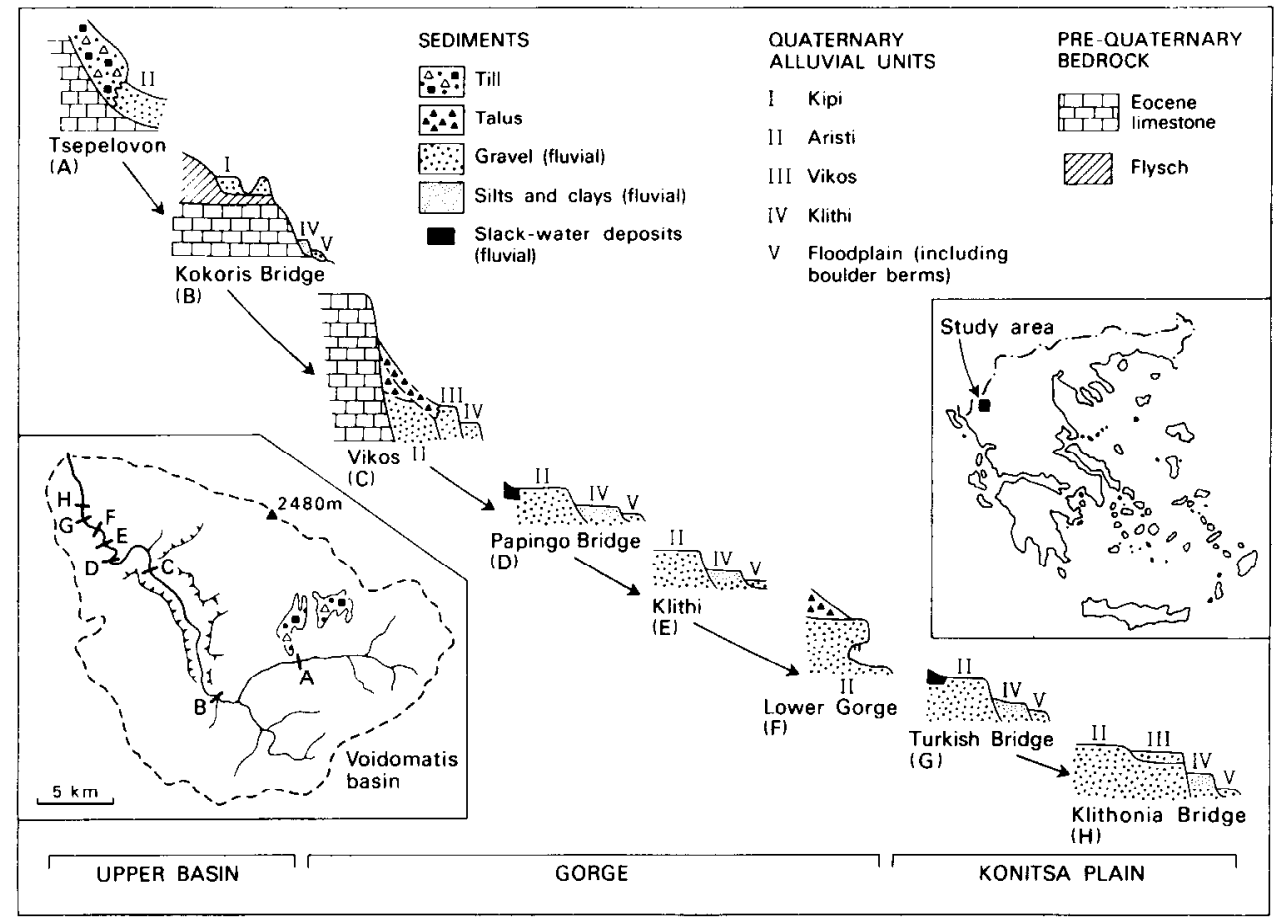

Figure 1. Different fills and the terraces they form.

other coarse fills of "Older Fill" type, the Kipi and Vikos units, forming terraces at different heights, and one fine-grained Holocene alluvial fill, the Klithi unit (Figure 1).

We have analysed the lithological composition of the larger ( $>8 \mathrm{~mm}$ ) clasts (Table 1), and the mineralogy of the fines by XRD analysis (Figure 2). Both techniques show a clear separation between the different units, and the Aristi unit is particularly distinctive in the dominance of limestone lithologies. The Voidomatis basin contains a number of geologically distinctive and geographically discrete sources of sediment, and the varying input of these sources to the composition of successive alluvial fills not only provides a useful means of stratigraphic discrimination and correlation, but also sheds light on the genesis of each fill. The uppermost part of the Voidomatis basin is developed on limestones of Palaeocene to Eocene age, and it is in this part of the basin where evidence of recent glaciation is found. Corries and stepped, U-shaped valleys are present, with impressive arcuate moraine features. The Aristi unit can be traced as an outwash train from the former glacier margins and it is lithologically identical to local glacial sediments. The middle and lower reaches of the basin are developed on extensive tracts of late Eocene flysch. Ophiolite outcrops occur in the eastern part of the basin. When the Aristi unit was being deposited, sediment supply was entirely dominated by the large quantities of limestone-derived material carried into the river by glacial action. The other alluvial fills have significant components of flysch and igneous materials. When they were being deposited, glaciation in the upper reaches of the catchment was much reduced or absent, and unglaciated parts of the basin at lower altitude provided a more important source of sediment.

Dates have been obtained for material sampled from sedimentary units using ${ }^{14} \mathrm{C}$, TL and ESR techniques. These show that the Kipi unit (which is exposed at only one site in the 


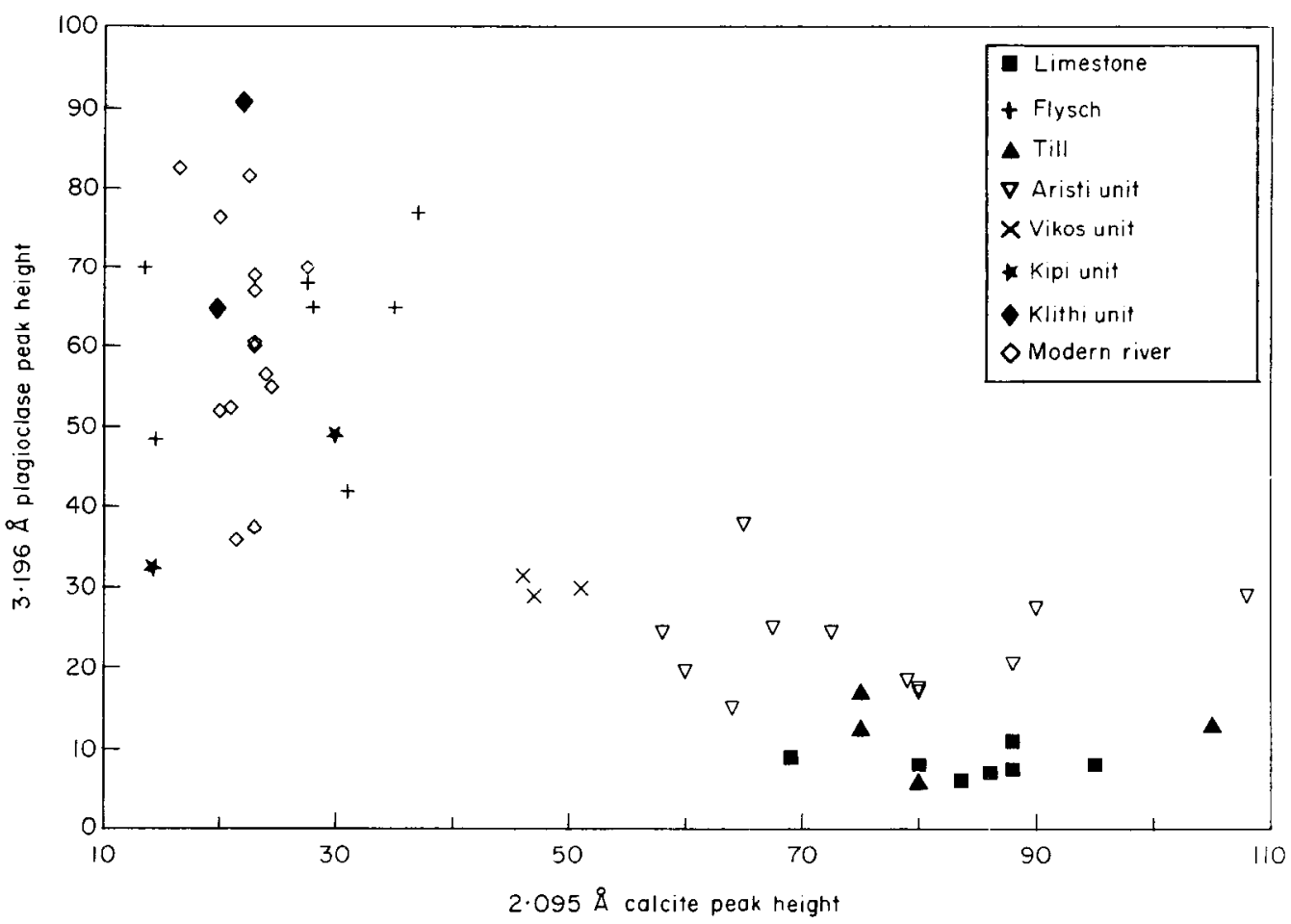

Figure 2. Mineral composition of the fines by XRD analysis.

Table 1. Coarse fraction lithologies of Voidomatis alluvial units

\begin{tabular}{|c|c|c|c|c|c|c|}
\hline \multirow{2}{*}{$\begin{array}{l}\text { Alluvial } \\
\text { unit }\end{array}$} & \multirow{2}{*}{$\begin{array}{l}\text { Samples } \\
\underset{N}{ }\end{array}$} & \multirow{2}{*}{$\begin{array}{c}\text { Clasts } \\
N\end{array}$} & \multicolumn{4}{|c|}{ Lithological composition $(\%)$} \\
\hline & & & Limestone & Flysch & Flint & Igneous \\
\hline Klithi & 2 & 1139 & $69 \cdot 3$ & $29 \cdot 6$ & $1 \cdot 0$ & $0 \cdot 1$ \\
\hline Vikos & 2 & 695 & $82 \cdot 3$ & 12.8 & 0.6 & $4 \cdot 3$ \\
\hline Aristi & 9 & 5680 & 94.6 & $3 \cdot 1$ & $2 \cdot 2$ & $0 \cdot 1$ \\
\hline Kipi & 1 & 361 & $18 \cdot 7$ & 36.7 & 0.9 & $44 \cdot 0$ \\
\hline
\end{tabular}

upper basin) is older than 150,000 years BP (VOI26). The Aristi unit has given TL and ESR dates of between 24,300 and 28,200 years BP. ESR dates were obtained on three enamel pieces of a red deer tooth. Two sets of ages are calculated (see Grün et al., 1987; Grün, 1989). The first set assumes an early U-uptake (EU) and gives the youngest possible ages. The second set assumes a continuous linear U-uptake (LU), which normally agrees with independent age estimates. The results are as follows:

EU

571a

$571 \mathrm{~b}$

$571 \mathrm{c}$
$15,700 \pm 2800$

$16,400 \pm 1200$

$15,400 \pm 1700$
LU

$25,000 \pm 500$

$26,000 \pm 1900$

$24,300 \pm 2600$ 
The TL age of the Aristi unit is $28,200 \pm 7100$ years BP (VOI23) which closely agrees with the LU set of ESR dates. Fines from the Vikos unit have been dated by TL to $19,600 \pm 3000$ years BP (VOI24). The ${ }^{14} \mathrm{C}$ dates from the Klithi unit range in age from 1000 years BP to modern (Bailey et al., 1986b).

We interpret these dates as indicating that the Aristi outwash relates to a Late Würm glaciation of the mountain parts of the catchment, which can be correlated with similar events elsewhere in Europe. The Vikos unit, with its materials from both glacial and nonglaciated terrains, we believe to be a deglacial unit produced by widespread runoff generation. The materials from the Klithi unit are equivalents of the "Younger Fill", relating to much more recent events involving historical land degradation and soil removal.

It is important to set the Palaeolithic occupation of the area more precisely into this framework. The oldest Palaeolithic (a flint artefact associated with deer teeth ESR dated to between 24,300 and 26,000 years BP) is found on the margins of the broad Konitsa basin at Klithonia Old Bridge (G, Figure 1). The finds are insufficient for any detailed archaeological interpretation, but they do provide evidence of a human presence during the maximum glaciation on open sites at low elevation, although not in the gorge itself.

Four rockshelters with evidence of Palaeolithic occupation have been discovered in the lower reaches of the Voidomatis valley, two on the edge of the Konitsa basin, and two within the gorge. Only the latter two have so far been excavated and the material is currently under detailed investigation. Of these Klithi is the largest of all the rockshelters, and has immensely rich deposits with very large flint and bone assemblages indicating specialization, probably of a seasonal nature, on the exploitation and processing of carcases of ibex (Capra capra) and chamois (Rupicapra rupicapra) Bailey et al., 1984, 1986a). A smaller assemblage of similar type is present at the nearby site of Megalakkos. Both sites show evidence of use between 17,000 and 10,000 years BP (Bailey et al., 1986b; Bailey \& Thomas, 1987) but absence or rarity of occupation before and after this interval.

An open-air hearth with Palaeolithic artefacts has also been discovered near Klithonia Old Bridge (Webley \& Sturdy, unpubl.) and has provided ${ }^{14} \mathrm{C}$ dates on charcoal of $10,700 \pm 200(\mathrm{OxA}-353)$ and 11,100 \pm 200 (OxA-351) years BP (Bailey et al., 1986b). Humic acids from the charcoal gave earlier dates: 14,600 \pm 340 (OxA-372) and $15,840 \pm 250$ (OxA-352) years BP, but these are thought to be less reliable because of possible contamination (see Gillespie et al., 1985). We believe this hearth was formed on the surface of a terrace, probably above the river level at the time, and then subsequently buried by river and slope wash deposits. To judge from the detailed rockshelter excavations, this open site coincides with the end of Palaeolithic occupation in the lower gorge, where renewed deposition of cave talus provides some local evidence for the return of cold-climate conditions which may be equivalent to the Younger Dryas cold phase.

Our archaeological interpretation therefore is that use of the rockshelters within the gorge and exploitation of the adjacent mountain slopes took place in Late Würm times in the interval between full glacial conditions and the renewed climatic deterioration at the end of the Late Glacial. During this interval the Voidomatis valley floor was filled to a much greater extent than at present with gravels derived from mountain glaciation. Today the rockshelters within the gorge are difficult of access above steep talus slopes $30 \mathrm{~m}$ above the river, but their Palaeolithic inhabitants would have looked out over a broader, gravelbottomed valley floor only $12 \mathrm{~m}$ below their feet, with the active braided river a few metres below that. Nodules of river-rolled black flint which provided the main source of raw material for their stone artefacts would have been more abundantly available in the limestone-dominated lithology of the Aristi unit than in the present-day river gravels. The mountain slopes above Klithi would also have provided an ideal seasonal habitat for ibex and chamois under Late Glacial conditions. We conclude that the concentration of occupation at Klithi between about 17,000 and 10,000 years BP is related to environmental 
changes associated with local glaciation which created a "window" of ideal conditions for the use of the gorge as a seasonal base for ibex and chamois exploitation during the Late Glacial period.

Finally we wish to draw attention to the significance of the Kipi unit of the Voidomatis. This coarse, reddened, fluvial deposit is strongly weathered, lithologically distinctive, and is at a considerable elevation above the modern valley floor. We believe this will correlate with some of the "red beds" from Epirus and elsewhere in the Mediterranean (Pope et al., 1984), but it is clearly much older than the Late Würm and the evidence of Palaeolithic occupation we have described. The means for distinguishing more precisely between different stages of the "Older Fill" is now opening up, and we anticipate that the application of detailed lithostratigraphic work, with the use of modern dating techniques wherever datable material is available, will provide an improved framework of value both to the study of Quaternary environments and of Palaeolithic archaeology.

\section{Acknowledgements}

We thank the British Academy, the British School at Athens, the National Geographic Society and the Society of Antiquaries for financial assistance in the field, the SERC for the support of JCW, the Faculty of Earth Sciences, Cambridge for XRD facilities, and the Ministry of Culture Athens, IGME Athens, the Ephorate of Speleology and Palaeoanthropology Athens, the Ephorate of Prehistoric and Classical Antiquities Ioannina, the Village Council of Klithonia, and the Metropolitanate of Konitsa for fieldwork permits. We are grateful to the following for facilitating dating and discussion of results: for ${ }^{14} \mathrm{C}$ dating, J. A. J. Gowlett and R. A. Housley of the Oxford Radiocarbon Accelerator Unit; for TL, N. C. Debenham of the British Museum Research Laboratory; and for ESR, R. Grün of the Sub-Department of Quaternary Research, Cambridge University. We also thank J. A. J. Gowlett, D. A. Sturdy and D. P. Webley for contributing observations in the field and comments on the text.

\section{References}

Bailey, G. N. \& Thomas, G. (1987). The use of percussion drilling to obtain core samples from rockshelter deposits. Antiquity 61, 433-439.

Bailey, G. N., Carter, P. L., Gamble, C. S., Higgs, H. P. \& Roubet, C. (1984). Palaeolithic investigations in Epirus: the results of the first season's excavations at Klithi, 1983. Annual of the British School of Archaeology at Athens 79, 7-22.

Bailey, G. N., Gamble, C. S., Higgs, H. P., Roubet, C., Sturdy, D. A. \& Webley, D. P. (1986a). Palaeolithic investigations at Klithi: preliminary results of the 1984-1985 field seasons. Annual of the British School of Archaeology at Athens 81, 7-35.

Bailey, G. N., Gamble, C. S., Higgs, H. P., Roubet, C., Webley, D. P., Gowlett, J. A. J., Sturdy, D. A. \& Turner, C. (1986b). Dating results from palaeolithic sites and palaeoenvironments in Epirus (north-west Greece). In (J. A. J. Gowlett \& R. E. M. Hedges, Eds) Archaeological Results from Accelerator Dating. Oxford: Oxford University Committee for Archaeology, pp. 99-107.

Gillespie, R., Gowlett, J. A. J., Hall, E. T., Hedges, R. M. \& Perry, C. (1985). Radiocarbon dates from the Oxford AMS System: archaeometry datelist 2. Archaeometry 27, 237-246.

Grün, R. (1989). Die ESR-Altersbestimmungsmethode. Berlin-Heidelberg, Springer.

Grün, R., Schwarcz, H. P. \& Zymela, S. (1987). ESR dating of tooth enamel. Canadian Journal of Earth Sciences 24, 1022-1037.

Higgs, E. S. \& Vita-Finzi, C. (1966). The climate, environment and industries of Stone Age Greece, part II. Proceedings of the Prehistoric Society 32, 1-29. 
Pope, K. O. \& Van Andel, T. H. (1984). Late Quaternary alluviation and soil formation in Southern Argolid: its history, causes and archaeological implications. Journal of Archaeological Science 11, 281-306.

Pope, K. O., Runnels, C. N. \& Teh-Lung, K. (1984). Dating Middle Palaeolithic red beds in southern Greece. Nature 312, 264-266.

Vita-Finzi, C. (1969). The Mediterranean Valleys: Geological Changes in Historical Times. Cambridge: Cambridge University Press. 